\title{
Quality characteristics and antioxidant activities of ganache added with Porphyra tenera powder
}

\author{
Min Ah Park ${ }^{1}$, Kun Jong Lee ${ }^{2}$, Su Jin Kim ${ }^{1}$, Mee Ree Kim ${ }^{1 *}$ \\ ${ }^{\prime}$ Department of Food and Nutrition, Chungnam National University, Daejeon 34134, Korea \\ ${ }^{2}$ Department of Food and Nutrition, Soongeui Women's College, Seoul 04628, Korea
}

\section{김 분말 첨가 가나슈의 이화학적 - 관능적 품질 특성 및 항산화 활성}

\author{
박민아 ${ }^{1} \cdot$ 이근종 ${ }^{2} \cdot$ 김수진 $^{1} \cdot$ 김미리 $^{1 *}$ \\ ${ }^{1}$ 충남대학교 식품영양학과, ${ }^{2}$ 숭의여자대학교 식품영양학과
}

\begin{abstract}
The purpose of this study was to investigate the quality characteristics and antioxidant activities of ganache added with Porphyra tenera powder (PTP). The levels of PTP addition to ganache were $0,1,2$, and $3 \mathrm{wt} \%$. The lightness (L) and yellowness (b) values of the ganache in the Hunter color system decreased upon increasing the amount of PTP. In addition, textural examinations showed that the hardness of the ganache increased upon PTP addition. Furthermore, sensory evaluations indicated that the overall acceptability score was highest for the ganache chocolate containing $1 \%$ PTP, whereby the color, flavor, and taste scores were the highest. Meanwhile, the moisture content decreased upon increasing the PTP content, which differed significantly from the control. Moreover, the sugar content ( ${ }^{\circ}$ Brix) and reducing sugar content increased upon increasing the PTP content. It was also found that the phycocyanin and chlorophyll contents in the ganache containing 3\% PTP were higher than for the other samples, and the total phenolics and flavonoid contents increased upon increasing the amount of added PTP. Finally, the DPPH radical scavenging and SOD-like activities of the ganache increased with greater quantities of PTP. These results, therefore, indicate that the addition of PTP to ganache chocolate can lead to the manufacture of high quality chocolate with a high antioxidant activity.
\end{abstract}

Key words : Porphyra tenera, laver, ganache, antioxidant activities, quality characteristics

서 론

현대사회의 급격한 변화 속에 최근 소비자들은 삶의 질과 건강한 식생활에 관심이 높아지고, 각종 건강정보의 영향으로 기존의 재료보다는 기능성 부재료를 첨가한 건 강 지향적인 제품을 원하고, 수요계층별 기호뿐만 아니라, 차별화가 될 수 있는 건강기능식품에 대한 개발 욕구가 증대되고 있다(Kweon, 2003). 또한, 증가하고 있는 성인병 의 치료와 예방을 위하여 현대 의학의 기술적인 면에만 의존하기보다는 기능성 식품으로부터 생리활성 물질을
얻거나, 핵심 치료물질을 찾고 있는 추세이다(Kwon과 Sung, 1997). 이에 다양한 기능성을 가진 해조류를 첨가하 여 건강기능식품의 개발의 필요성이 대두되고 있는 실정 이다(Lee 등, 2017). 해조류는 우리나라를 비롯한 동양권 에서 식용하는 식품으로, 해조의 세계 생산량은 연간 대략 4 백만 톤이다. 이 생산량의 $80 \%$ 이상이 아시아의 태평양 지역에서 생산되며, 이 중 상당 부분을 중국, 일본 및 한국 에서 생산하여 소비하고 있다(Huang과 Huanf, 1999).

우리나라의 대표적인 해조류인 김(Porphyra tenera)은 한국, 일본, 중국에서 주로 소비되고 있으며, 전 세계 50여

*Corresponding author. E-mail : mrkim@cnu.ac.kr, Phone :+82-42-821-6837, Fax :+82-42-821-8671

Received 27 December 2019; Revised 13 February 2020; Accepted 10 April 2020.

Copyright (c) The Korean Society of Food Preservation.

This is an Open Access article distributed under the terms of the Creative Commons Attribution Non-Commercial License (http://creativecommons.org/licenses/by-nc/4.0) which permits unrestricted non-commercial use, distribution, and reproduction in any medium, provided the original work is properly cited. 
종 정도 분포하며, 우리나라의 남해안 일대에는 10 여 종 정도가 오래전부터 양식되고 있다(Lee 등, 2000). 김은 보라 털과(Bangiceae)에 속하는 홍조류로 한국인의 식생활에 중요한 위치를 차지하는 해조류로 주로 조미 김 등으로 가공하여 부식으로 소비되어왔으며, 최근에는 미국을 비 롯한 해외에서도 스낵 등으로 소비가 확장되고 있다(Park 등, 2005). 예로부터 미역 및 다시마 등의 해조류는 미네랄 과 식이섬유 등의 영양 공급원으로 이용되어왔고, 단백질 과 비타민 $\mathrm{A}$, 비타민 $\mathrm{B}$ 군, 오메가 3 지방산, 콜레스테롤을 낮추는 타우린이 풍부한 식품이다(Kim 등, 1988; Jenkins 등, 2000). 또한, 마른 김에는 칼륨, 인, 마그네슘, 칼슘, 망간, 아연, 구리, 요오드, 철, 코발트 등의 무기질이 함유 되어 있다(Hwang, 2013). 김은 전체 생산량의 $70 \%$ 가 전라 남도 남해안 일대에서 생산되고 있으며, 미역 다음으로 많이 생산되고(Park 등, 2001a), 양식기술 및 가공기술의 발달로 2018년 해조류 양식 생산량의 $32 \%$ 를 차지할만큼 경제적으로도 중요한 위치를 점하고 있으며, 향후에도 지 속적으로 생산량이 증가할 것으로 내다보고 있다(MOF, 2019).

최근에는 갑상선 질환 증가와 일본 후쿠시마원자력발 전소의 폭발과 관련하여 요오드 섭취의 필요성이 부각되 면서 해조류의 무기질을 포함한 영양성분 관련 식품학적 연구의 필요성(Bae, 2006)과, 육상자원 고갈로 해양자원의 새로운 활용 연구가 필요한 시점에 해조산업의 발전과 김의 활용도를 높이기 위한 개발 연구가 필요한 실정이다 (Lee 등, 2017).

Lee 등(2002)의 연구에서는 끈적한 성분인 포피란 (porphyran)과 불용성 식이섬유 섭취로 콜레스테롤 저하 작용과 고지혈증의 개선 효과, Cho 등(1990)은 당단백질 의 항암효과와 면역 활성, Jung 등(2002)은 생체조절 유지 및 질병 예방의 효과와 항산화 효과 연구로 다양한 생리활 성 물질을 가진 연구결과가 부각되고 있다.

가나슈는 다크 초콜릿과 생크림을 혼합하여 만드는 초 콜릿 크림으로 주로 초콜릿 속의 충전물로 사용된다. 부드 러운 식감이 큰 특징으로 주로 수제 초콜릿에 사용되며, 향신료와 과일 등과 같은 부재료를 첨가하여 다양한 맛과 향을 내기도 한다(Youn과 Lee, 2012). 최근에는 초콜릿 관련 기능성 연구도 활발하게 이루어지고 있으며, 초콜릿 의 주원료인 카카오 열매의 다양한 기능성에 관한 근거자료 가 보고되고 있다. Charalambos 등(2006); Park과 Joo(2011); Rein 등(2000)의 연구에서 심혈관 질환 예방뿐만 아니라, 항암효과, 노화방지, 면역력 증진 및 스트레스 감소 효과 까지 다양한 기능성에 대해 보고되었다. 또한, $\mathrm{HDL}$-콜레 스테롤 수치를 높이고, 체내 지방분해에 효과가 있으며, 폴리페놀의 일종인 플라보노이드 항산화 물질이 함유되 어 있어 산화방지 효과가 높은 것으로 보고됨에 따라(Lee
와 Jang, 2014) 최근 기호 식품을 벗어나 건강기능식품으 로서 각광을 받고 있다. 매년 $10-16 \%$ 의 증가세를 보이고 있는(Choi 등, 2014) 국내 초콜릿 시장은 1980년대 이후부 터 급격한 성장을 이루고 있으며, 세계 초콜릿 시장의 동 향도 2018년까지 시장규모가 연평균 7\% 내외로 성장할 것으로 전망되어 초콜릿 시장의 꾸준한 성장이 기대된다 (Kim과 Lee, 2015).

그동안 지역특산물을 이용하여 초콜릿을 개발한 연구 사례로는 버찌분말을 첨가한 초콜릿(Yoon 등, 2009), 발효 숙성마늘 추출물 첨가 초콜릿(Shin과 Joo, 2010), 숙지황 농축액 첨가 초콜릿(Kim 등, 2012a), 오디박 분말 첨가 초콜릿(Hwang 등, 2012) 등을 활용한 연구가 이루어졌다. 따라서 최근 건강에 관한 소비자의 관심 증대로 다양한 기능성을 부여한 식품 개발의 확대와 더불어 영양적 가치 가 우수하고 생산 및 수요가 높지만, 소비 형태가 한정적 인 김을 디저트에 접목시켜 활용하고자 김 분말을 이용한 초콜릿 제품을 개발하였다. 이러한 소비자의 다양한 기호 에 대한 소비 옥구를 충족시키기 위해 초콜릿을 제조하여 품질 특성을 연구하고, 기능성 평가를 시행하여 지역특산 물 활성화와 상품적 가치 유무를 조사하고자 한다.

\section{재료 및 방법}

\section{실험재료}

본 실험에서 사용된 김은 김 분말(2019년 구매, 맑은들 (주), Hongcheon, Korea)을 구입하여 $-70^{\circ} \mathrm{C}$ 에서 냉동보관 (Ultra-Low Temperature Freezer SW-UF-400P, Samwon Freezing Engineering Co., Busan, Korea)하여 사용하였다. 이외에 화이트 초콜릿(Chocolate Blanc Satin, Ballycallebaut Chocolate Co., Ltd., Lebbeke Wieze, Belgium), 다크 초 콜릿(Couverture Noire Excellence, Ballycallebaut Chocolate Co., Ltd.), 애플 퍼커(De Kuyper Royal Distillers, Schiedam, Netherlands), 생크림(덴마크 생크림S, Dongwon F\&B Co., Ltd., Suwon, Korea)을 사용하여 김 분말 첨가 가나슈를 제조하였다.

\section{가나슈 초콜릿 제조}

김 분말 가나슈의 재료 배합비는 Table 1 과 같으며, 가나 슈 초콜릿의 제조 과정은 Fig. 1에 나타내었다. 대조군은 김 분말을 첨가하지 않았으며, 실험군은 김 분말을 가나슈 의 전체 총량의 $1,2,3 \%$ 를 첨가하여 제조하였다. 김 분말 을 첨가한 가나슈 제조방법은 화이트 초콜릿을 중탕 볼에 넣어 중탕으로 $40-45^{\circ} \mathrm{C}$ 까지 녹인 후, $26^{\circ} \mathrm{C}$ 까지 온도를 낮춘 다음 $28-29^{\circ} \mathrm{C}$ 까지 다시 올려 탬퍼링하였다. 생크림 은 $90^{\circ} \mathrm{C}$ 정도 끓인 다음 $32^{\circ} \mathrm{C}$ 까지 온도를 낮춘 후 탬퍼링한 화이트 초콜릿에 조금씩 넣어가며 혼합해주고, 김 분말을 
Table 1. Ingredient composition of ganache added with different amounts of Porphyra tenera powder

(unit: g)

\begin{tabular}{ccccc}
\hline Ingredients & Control $^{1)}$ & PTP1 & PTP2 & PTP3 \\
\hline Porphyra tenera powder & 0 & 1 & 2 & 3 \\
White chocolate & 60 & 60 & 60 & 60 \\
Fresh cream & 30 & 29 & 28 & 27 \\
Apple pucker & 8 & 8 & 8 & 8 \\
\hline Total weight & 98 & 98 & 98 & 98 \\
\hline
\end{tabular}

${ }^{1)}$ Control, ganache without Porphyra tenera powder; PTP1, 1\% Porphyra tenera powder ganache; PTP2, 2\% Porphyra tenera powder ganache; PTP3, 3\% Porphyra tenera powder ganache.

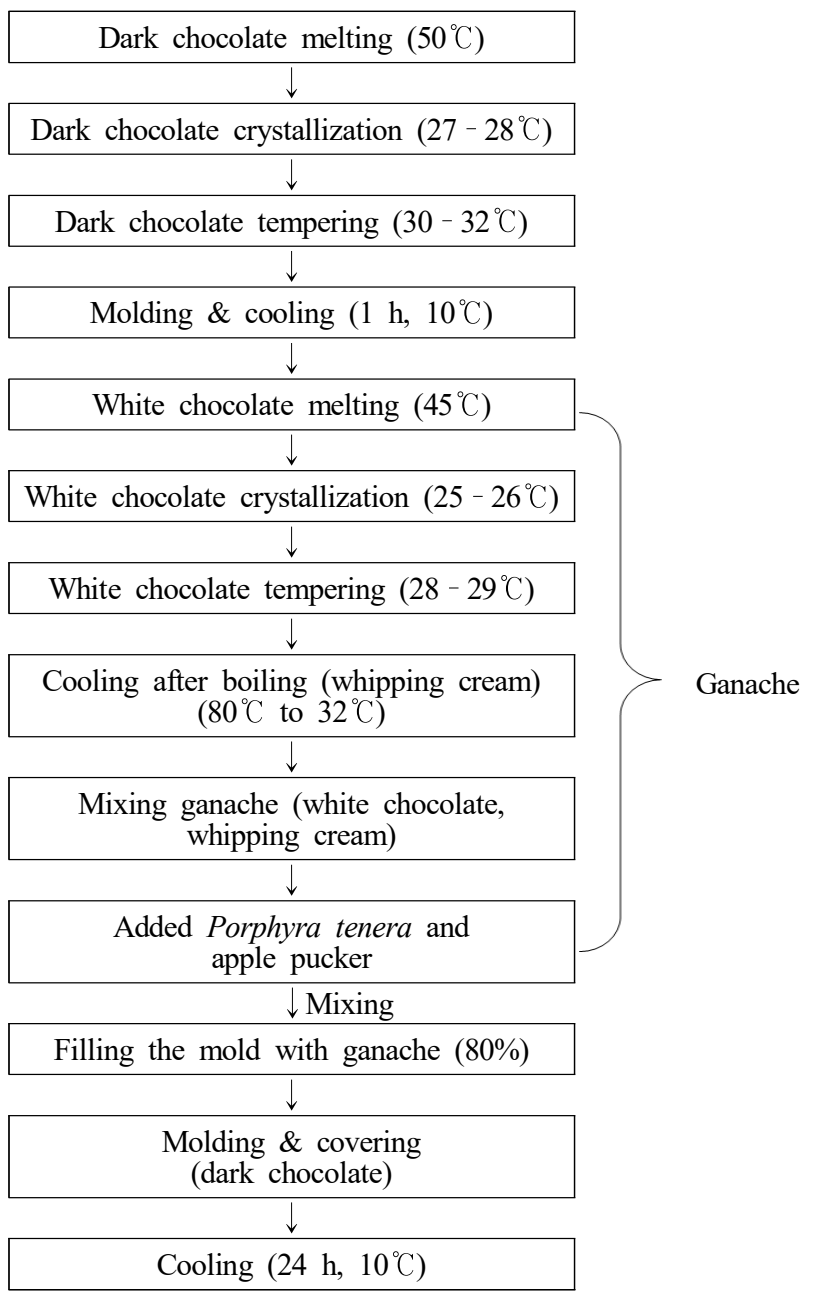

Fig. 1. Process for preparation of ganache chocolate added with Porphyra tenera powder.

첨가하여 믹싱한 후 마지막 애플 퍼커를 넣고 재빨리 섞어 주었다. $15 \times 15 \times 1 \mathrm{~cm}($ width $\times$ depth $\times$ height $)$ 의 정사각형 틀 에 가나슈를 부어 $10^{\circ} \mathrm{C}$ 에서 하루 동안 굳힌 뒤 시료로
사용하였다. 수분, 당도 및 환원당, $\mathrm{pH}$ 및 산도, 피코시아 닌, 클로로필, 색도, 조직감, 총 페놀, 플라보노이드, $\mathrm{DPPH}$ radical 소거능, SOD 유사활성은 가나슈를 시료로 사용하 였고, 관능평가는 기능성 초콜릿의 제품화를 위한 목적으 로 다크 초콜릿의 커버춰로 하트 초콜릿 몰드(Chocolate world, Antwerpen, Belgium)에 몰딩하여 커버를 만들고, 속을 가나슈로 $80 \%$ 채운 후 다시 커버를 씨워 굳혀서 초콜 릿 형태로 평가하였다.

\section{색도 측정}

색도는 색차계(Spectrophotometer CM-600, Konica Minolta Sensing, Inc., Tokyo, Japan)를 사용하여 Hunter's color system의 L값(lightness), $a$ 값(redness), $b$ 값(yellowness)을 총 3 회 반복 측정하여 평균값으로 나타내었다. 김 가나슈를 페트리디쉬 $(60 \times 12 \mathrm{~mm})$ 에 빈 공간이 생기지 않게 담아 색도 를 측정하였다. Standard color value는 L값 99.35 , a값 - 0.15 , $\mathrm{b}$ 값 -0.05 인 calibration plate를 표준으로 사용하였다.

\section{조직감 측정}

조직감은 시료를 $1.5 \mathrm{~cm}$ 높이의 트레이에 넣어 냉장고 에 30분간 굳힌 후 texture analyser(TA/XT2, Stable Micro System Ltd., Surrey, England)를 사용하여 물성 변화를 통 해 확인하였다. 지름 $5 \mathrm{~mm}$ 의 plunger를 이용하여 경도 (hardness), 탄력성(springiness), 응집성(cohesiveness), 검성 (gumminess), 씹힘성(chewiness)을 5 회 이상 측정하였다. 기기 작동 조건은 Table 2 와 같다.

\section{관능평가}

김 분말을 첨가한 가나슈를 다크 초콜릿으로 몰딩한 가나슈 초콜릿의 관능평가는 강도와 기호도 검사를 실시 하여 평가하였다(충남대학교 생명윤리위원회 생명윤리 면제심의 윤리면제 승인번호: 201807-SB-112-01). 강도 검 사는 예비검사를 통해 관능검사에 익숙한 식품영양학과 재학생 8 명을 패널로 선정하여 검사방법과 평가특성을 교육한 후, 강도(1점; 매우 약함, 7점; 매우 강함) 평가를 7점 척도법으로 하였다. 강도 검사의 항목은 외관(색, 단면 의 매끄러운 정도), 향(김향, 단향, 초콜릿향), 맛(김맛, 단 맛, 크림맛, 쓴맛), 조직감(경도, 점착성)에 대하여 실시하 였다. 기호도 검사는 관능요원으로 19 세 이상의 일반인 50 명을 대상으로 충분한 지식과 용어, 평가기준 등을 숙지 시킨 후 실험에 응하도록 하였고, 평가척도는 7점 척도법 으로 하였다. 기호도 검사의 항목은 색, 향, 맛, 조직감, 전반적인 기호도, 구입할 의향에 대하여 실시하였다. 시료 는 세 자리 난수표를 부착한 일회용 접시에 제공하였고, 다음 시료 평가에 미치는 영향을 줄이기 위해 따뜻한 물과 함께 제공하였다. 
Table 2. Condition of texture analyser

\begin{tabular}{cc}
\hline Apparatus & Condition \\
\hline Diameter of plunger & $5 \mathrm{~mm}(\mathrm{p} / 5)$ \\
Pre-test speed & $2.0 \mathrm{~mm} / \mathrm{s}$ \\
Test speed & $2.0 \mathrm{~mm} / \mathrm{s}$ \\
Post-test speed & $2.0 \mathrm{~mm} / \mathrm{s}$ \\
Distance & $20 \%$ \\
Trigger type auto & $5 \mathrm{~g}$ \\
\hline
\end{tabular}

\section{수분 함량 측정}

수분 함량은 시료를 약 $1.0 \mathrm{~g}$ 씩 취하여 $110^{\circ} \mathrm{C}$ 로 설정된 적외선 수분측정기(Infrared Moisture Analyzer FD-660, Kett Electric Laboratory, Tokyo, Japan)를 이용하여 3회 반 복 측정하였다.

\section{당도 및 환원당 측정}

당도는 시료 $5 \mathrm{~g}$ 에 $40^{\circ} \mathrm{C}$ 의 증류수 $45 \mathrm{~mL}$ 를 넣어 희석하 여 균질화한 후, $40^{\circ} \mathrm{C}$ 의 sonication(Powersonic 420, Hwashin Technology, Gwangju, Korea)에서 30분 동안 침지시킨 다 음, $4,326.7 \times g$ 으로 20 분간 원심분리(Combi-514R, Hanil, Hwaseong, Korea)하여 상등액을 취해 당도계(SCM-1000, HM Digital, Seoul, Korea)로 측정하였다. 환원당의 시료는 당도의 시료와 동일하며, dinitrosalicylic acid(DNS)에 의한 비색법으로 분광광도계(Epoch Microplate Spectrophotometer, BioTeck Instruments, Winooski, VT, USA)를 사용하 여 $550 \mathrm{~nm}$ 에서 흡광도를 측정하였다. 표준곡선은 glucose (Sigma-Aldrich Co., St. Louis, MO, USA)를 농도별로 반응 시켜 사용하였다.

\section{$\mathrm{pH}$ 및 산도}

$\mathrm{pH}$ 는 시료 $5 \mathrm{~g}$ 을 증류수 $45 \mathrm{~mL}$ 에 희석하여 균질화한 후, $40^{\circ} \mathrm{C}$ 의 sonication(Powersonic 420, Hwashin Technology)에서 30 분 동안 침지시킨 다음, $4,326.7 \times g$ 으로 20 분간 원심분리 (Combi-514R, Hanil)하여 취한 상층액을 $\mathrm{pH}$ meter(420 Benchtop, Orion Research, Beverly, MA, USA)로 측정하였다. 산도의 시료는 $\mathrm{pH}$ 의 시료와 동일하게 준비하여 상층액 10 $\mathrm{mL}$ 를 취하여 $\mathrm{pH}$ 8.3까지 적정하는데 필요한 $0.1 \mathrm{~N} \mathrm{NaOH}$ 양 $(\mathrm{mL})$ 을 citric acid 함량(\%)으로 환산하여 총산 함량을 표 시하였다.

$$
\text { Acidity }(\%)=\frac{\mathrm{mL} \text { of } 0.1 \mathrm{NaOH} \times 0.0064}{\text { Weight of sample }} \times 100
$$

\section{피코시아닌 및 클로로필 정량}

피코시아닌은 시료 $2 \mathrm{~g}$ 을 $100 \%$ 에탄올 $20 \mathrm{~mL}$ 와 혼합한 후에 sonication(Powersonic 420, Hwashin Technology)에 4 $0^{\circ} \mathrm{C}$ 에서 200 분 동안 반응시킨 뒤, 냉장고 $\left(4^{\circ} \mathrm{C}\right)$ 에서 24 시간 침지시켰다. 그리고 원심분리기(Combi-514R, Hanil)에서 $4,326.7 \times g, 4^{\circ} \mathrm{C}$ 로 20 분간 원심 분리하여 여과한 상층액을 취해 엘라이저(Epoch Microplate Spectrophotometer, BioTeck Instruments)를 사용하여 $620 \mathrm{~nm}, 652 \mathrm{~nm}$ 에서 흡광도를 측정하였다. 측정한 흡광도 값을 아래의 식을 통해 피코시 아닌 함량을 계산하여 가나슈 $100 \mathrm{~g}$ 에 대한 피코시아닌 함량으로 나타내었다.

클로로필은 시료 $2 \mathrm{~g}$ 을 dimethyl sulfoxide(DMSO, Daejung Chemicals and Metals Co., Ltd., Siheung, Korea) $20 \mathrm{~mL}$ 에 넣어 희석하여 균질화한 후, $40^{\circ} \mathrm{C}$ 의 암조건에서 24 시간 동안 색소를 추출한 후, centrifuge(Combi-514R, Hanil)에서 $4,326.7 \times g$ 으로 20 분간 원심분리하여 취한 상층액을 엘라 이저(Epoch Microplate Spectrophotometer, BioTeck Instruments)를 이용하여 $664,648 \mathrm{~nm}$ 에서 흡광도를 측정하였다. 측정한 흡광도 값을 아래의 식을 통해 클로로필 함량을 계산하여 가나슈 $100 \mathrm{~g}$ 에 대한 클로로필 함량으로 나타내 었다. 클로로필 추출 및 측정은 Chappelle 등(1992)의 방법 에 준하여 실험하였다.

C-phycocyanin $(\mathrm{mg} / \mathrm{mL})=[\mathrm{A} 620-0.474(\mathrm{~A} 652)] / 5.34$

Allophycocyanin $(\mathrm{mg} / \mathrm{mL})=[\mathrm{A} 652-0.208(\mathrm{~A} 620)] / 5.09$

Chlorophyll a $(\mu \mathrm{g} / \mathrm{mL})=12.25 \cdot \mathrm{A} 664-2.79 \cdot \mathrm{A} 648$

Chlorophyll b $(\mu \mathrm{g} / \mathrm{mL})=21.50 \cdot \mathrm{A} 648-5.10 \cdot \mathrm{A} 664$

Total chlorophyll $(\mu \mathrm{g} / \mathrm{mL})=$ Chlorophyll $\mathrm{a}+$ Chlorophyll $\mathrm{b}$

\section{총 페놀 정량}

총 페놀 함량은 Folin-Ciocalteu's법으로 실험하였다. Folin-Ciocalteu's phenol reagent가 알칼리 조건에서 노란색 을 띠는데 페놀성 물질에 의해 몰리브덴 청색으로 환원되 는 원리로 측정하였다(Singleton 등, 1999). 시료 $5 \mathrm{~g}$ 과 메탄 올 $50 \mathrm{~mL}$ 를 sonication(Powersonic 420, Hwashin Technology) $40^{\circ} \mathrm{C}$ 에서 4 시간 교반하고, 24 시간 냉장고에 보관 한 후 $4,326.7 \times \mathrm{g}, 4^{\circ} \mathrm{C}$ 로 20 분간 원심분리한다. 원심분리된 시료를 필터로 여과한 후 얻어진 상층액을 감압농축기 (EYELA SB-1000, Tokyo Rikakikai Co., Ltd., Tokyo, Japan) 로 용매를 휘발하여 추출물만 얻었다. 각각 추출물 200 $\mathrm{mg}$ 에 $1 \mathrm{~mL}$ 의 메탄올을 넣어 $200 \mathrm{mg} / \mathrm{mL}$ 농도의 추출물 용액을 시료 용액으로 사용하여 측정하였다. 시료 $50 \mu \mathrm{L}$ 에 증류수 $50 \mu \mathrm{L}$ 와 $0.2 \mathrm{~N}$ Folin-Ciocalteu reagent $500 \mu \mathrm{L}$ 를 넣고 3 분간 반응시킨 후 $7.5 \% \mathrm{Na}_{2} \mathrm{CO}_{3} 400 \mu \mathrm{L}$ 를 넣고 빛 차단 후 암실에서 30 분간 반응시킨 후 엘라이저(Epoch 
Microplate Spectrophotometer, BioTeck Instruments)를 이용 하여 $760 \mathrm{~nm}$ 에서 흡광도를 측정하였다. 표준곡선은 tannic acid(Yakuri Pure Chemicals Co., Ltd., Kyoto, Japan)를 사용 하여 가나슈 $100 \mathrm{~g}$ 에 대해 tannic acid 함량인 tannic acid equivalent(TAE) g/100 g으로 나타내었다.

\section{플라보노이드 정량}

플라보노이드의 시료 용액은 총 페놀 함량 실험에서 제 조한 $200 \mathrm{mg} / \mathrm{mL}$ 농도의 추출물 용액을 시료 용액으로 사 용하여 측정하였다. 시료 $100 \mu \mathrm{L}$ 에 $90 \%$ diethylene glycon $900 \mu \mathrm{L}, 1 \mathrm{~N} \mathrm{NaOH} 20 \mu \mathrm{L}$ 를 넣고 $37^{\circ} \mathrm{C}$ 의 water bath(VS1205W, Vision Scientific Co., Ltd., Daejeon, Korea)에서 1시 간 동안 반응시킨 후 엘라이저(Epoch Microplate Spectrophotometer, BioTeck Instruments)를 이용하여 $420 \mathrm{~nm}$ 에서 흡광도를 측정하였으며, 표준곡선은 naringin(Sigma-Aldrich Co.)을 사용하여 가나슈 $100 \mathrm{~g}$ 에 대해 naringin 함량인 $\mathrm{g}$ naringin equivalent(NE)/100 g으로 나타내었다.

\section{DPPH radical 소거능 측정}

DPPH radical 소거능의 시료 용액은 총 페놀 함량 실험 에서 제조한 $200 \mathrm{mg} / \mathrm{mL}$ 농도의 추출물 용액을 시료 용액 으로 사용하여 측정하였다. 농도별로 희석한 시료용액 50 $\mu \mathrm{L}$ 에 $1.5 \times 10^{-4} \mathrm{mM}$ 1,1-diphenyl-2-pircryhydrazyl(DPPH)용 액 $150 \mu \mathrm{L}$ 를 넣고 빛 차단 후 암실에서 30 분 동안 반응시킨 후 엘라이저(Epoch Microplate Spectrophotometer, BioTeck Instruments)를 이용하여 $515 \mathrm{~nm}$ 에서 흡광도를 측정하였 다. $\mathrm{DPPH}$ 라디칼 소거능 $(\%)$ 을 다음 식으로 계산하고, 농 도별 라디칼 소거능에 대한 검량선에서 $\mathrm{DPPH}$ 라디칼 소 거능이 $50 \%$ 가 되는 농도인 $\mathrm{IC}_{50}$ 값을 구하였다(Goldstein 등, 1979). Positive control로는 ascorbic acid를 사용하였고, 이 때 1 차 방정식은 $\mathrm{y}=837.91 \mathrm{x}+15.596\left(\mathrm{R}^{2}=0.9632\right)$ 이었으 며, ascorbic acid의 $\mathrm{IC}_{50}$ 값은 $0.542 \mathrm{mg} / \mathrm{mL}$ 이다.

Free radical scavenging activity $(\%)=$

$$
\frac{\text { Abs DPPH }- \text { Abs blank }}{\text { Abs DPPH }} \times 100
$$

\section{Superoxide dismutase(SOD) 유사활성 측정}

Superoxide dismutase(SOD)는 활성 산소종을 hydrogen peroxide $\left(\mathrm{H}_{2} \mathrm{O}_{2}\right)$ 로 전환하는 반응을 촉매하는 효소로 SOD 유사활성은 Marklund와 Marklund(1974)의 방법을 응용하 여 pyrogallol의 생성량을 측정하여 SOD 유사활성능으로 나타냈다. SOD 유사활성의 시료 용액은 총 페놀 함량 실 험에서 제조한 $200 \mathrm{mg} / \mathrm{mL}$ 농도의 추출물 용액을 시료 용 액으로 사용하여 측정하였다. 농도별로 희석한 시료 용액 $20 \mu \mathrm{L}$ 에 Tris- $\mathrm{HCl}$ buffer(10 mM EDTA) $260 \mu \mathrm{L}$ 와 $7.2 \mathrm{mM}$ pyrogallol $20 \mu \mathrm{L}$ 를 가하여 넣어 10 분간 반응시켰다 $\left(25^{\circ} \mathrm{C}\right)$. 반응액 중 pyrogallol의 양을 엘라이저(Epoch Microplate Spectrophotometer, BioTeck Instruments)를 이용하여 420 $\mathrm{nm}$ 에서 흡광도를 측정하였다. SOD 유사활성 $(\%)$ 은 시료 용액의 첨가구와 무첨가구 간의 흡광도 감소율을 나타내 며, 이를 통해 $\mathrm{EC}_{50}$ 값을 계산하였다. $\mathrm{SOD}$ 유사활성은 다 음과 같이 구하였다.

SOD-like activity $(\%)=$

$$
\left(1-\frac{\text { Abs sample }- \text { Abs blank }}{\text { Abs blank }}\right) \times 100
$$

\section{통계처리}

본 실험결과는 3회 이상 반복하여 측정한 값을 SPSS 24.0(Statistical Package for Social Science. SPSS Inc., Chicago IL, USA) software package 프로그램 중에서 기술 통계를 실시하여 평균과 표준 오차를 구하여 나타내었으 며, 분산분석(ANOVA)을 실시하여 유의성이 있는 경우에 Duncan의 다중범위검정(Duncan's multiple range test)을 이 용하여 시료 간의 유의차를 검정하였다 $(\mathrm{p}<0.05)$.

\section{결과 및 고찰}

\section{색도}

김 분말을 첨가한 가나슈의 색도는 Table 3 과 같다. 명도 는 김 분말을 첨가하지 않는 대조군에서 77.51 로서 김 분 말을 각각 $1,2,3 \%$ 첨가 시 각각 $59.13,52.11,42.29$ 로 김 분말 첨가량이 증가함에 따라 유의적으로 낮아졌다 $(\mathrm{p}<0.05)$. 이는 김 분말의 색이 어두워서 김 분말 첨가량이 증가할수록 가나슈의 색이 어두워지는 것으로 사료된다. 적색도는 대조군이 -1.69 , 김 분말을 $1,2,3 \%$ 첨가 시 $3.64,4.03,4.47$ 로 김 분말 첨가량이 증가함에 따라 적색도 가 유의적으로 증가하였다 $(\mathrm{p}<0.05)$. 김은 흑자색이나 흑갈 색을 띠고 있는데, 이는 김에 함유되어 있는 엽록소의 녹 색, 홍조소의 홍색, 남조소의 남색, 등색, 카로티노이드의 색소가 혼합되어 생긴 것으로 기인한다(Park, 2001b). 따라 서 가나슈에 김 첨가량이 증가함에 따라 홍조류인 적색색 소의 영향으로 적색도가 높아지는 것으로 사료된다. 황색 도는 김 분말을 첨가하지 않는 대조군이 16.95 로 가장 높 았으며, 김 분말을 $1,2,3 \%$ 첨가 시 $2.87,2.13,0.73$ 으로 김 분말 첨가량이 증가함에 따라 적색도와 반대로 유의적 으로 감소하였다 $(\mathrm{p}<0.05)$. Lee 등 $(2010)$ 의 매생이 분말을 첨가하여 제조한 쿠키의 연구에서도 매생이 분말 첨가량 이 증가함에 따라 명도와 황색도가 유의적으로 감소하는 유사한 결과를 나타냈다. Kweon 등(2003)의 김 분말을 첨 가한 스폰지 케이크의 품질 특성에서도 유사한 결과를 
Table 3. Color value of ganache added with different amounts of Porphyra tenera powder

\begin{tabular}{lccccc}
\hline & & Control $^{1)}$ & PTP1 & PTP2 & PTP3 \\
\hline \multirow{3}{*}{$\begin{array}{c}\text { Color } \\
\text { value }\end{array}$} & Lightness (L) & $77.51 \pm 0.09^{2) \mathrm{a} 3)}$ & $59.13 \pm 0.20^{\mathrm{b}}$ & $52.11 \pm 0.50^{\mathrm{c}}$ & $42.29 \pm 0.18^{\mathrm{d}}$ \\
& Redness (a) & $-1.69 \pm 0.02^{\mathrm{d}}$ & $3.64 \pm 0.08^{\mathrm{c}}$ & $4.03 \pm 0.08^{\mathrm{b}}$ & $4.47 \pm 0.03^{\mathrm{a}}$ \\
& Yellowness (b) & $16.95 \pm 0.02^{\mathrm{a}}$ & $2.87 \pm 0.10^{\mathrm{b}}$ & $2.13 \pm 0.14^{\mathrm{c}}$ & $0.73 \pm 0.06^{\mathrm{d}}$ \\
\hline
\end{tabular}

${ }^{1)}$ Control, ganache without Porphyra tenera powder; PTP1, 1\% Porphyra tenera powder ganache; PTP2, 2\% Porphyra tenera powder ganache; PTP3, 3\% Porphyra tenera powder ganache.

${ }^{2}$ All values are mean $\pm \mathrm{SD}$.

3)a-d Different letters in the same row are significantly different by Duncan's multiple range test at $\mathrm{p}<0.05$.

나타내었는데 이는 $\mathrm{pH}$ 및 온도 등에 영향을 받기 때문인 것으로 보고되어 김 분말 첨가량이 증가할수록 $\mathrm{pH}$ 가 낮아 져 색도에 영향을 미쳤을 것으로 사료된다. Lee 등(1987)의 연구 결과에 의하면 phycoerythrin은 chlorophyll과 carotenoid에 비해 열에 약하고, 수용성이므로 적색도가 온도 가 올라갈수록 현저히 감소하였다.

\section{조직감}

김 분말을 첨가한 가나슈의 조직감 측정결과는 Table 4 와 같다. 경도는 김 분말을 첨가하지 않는 대조군이 35.98 $\mathrm{g}$, 김 분말을 $1,2,3 \%$ 첨가 시 $79.57,115.47,135.80 \mathrm{~g}$ 으로 김 분말 첨가량이 증가할수록 유의적으로 증가하였다 $(\mathrm{p}<0.05)$. Yoon 등(2009)의 버찌분말을 첨가한 초콜릿의 항산화 활성 및 품질 특성, $\mathrm{Yu}$ 등(2007)의 복분자를 첨가 한 초콜릿의 최적 배합비, Kim 등(2012a)의 숙지황 농축액 첨가 초콜릿의 품질 특성 및 항산화성 연구에서도 유사한 결과를 나타내 수분 함량과 경도는 상관적 관계에 있는 것으로 보고된 바와 같이 수분 함량이 적은 김 분말 첨가 량이 많아질수록 경도가 높아진 것으로 사료된다. 또한, 발효숙성마늘 추출물을 첨가한 초콜릿의 제조(Shin과 Joo, 2010)연구에서 생크림의 함량에 따라 상호작용이 나타나 생크림 함량이 많을수록 경도가 낮아졌다는 연구결과와 같이 김 분말 첨가량을 증가시킬수록 생크림 함량을 줄였
고, 상대적으로 수분 함량이 적은 김 분말 첨가량을 증가 했기 때문에 초콜릿 수분 함량이 낮아져 경도가 높아진 것으로 사료된다. 원래대로 돌아가려는 성질을 의미하는 탄력성은 김 분말을 첨가하지 않는 대조군이 0.99 , 김 분말 을 $1,2,3 \%$ 첨가 시 $0.99,1.00,0.99$ 로 큰 차이가 없었다. 형태를 구성하기 위한 내부에서 필요한 힘을 의미하는 응집성은 김 분말을 첨가하지 않는 대조군이 0.46 , 김 분말 첨가량 증가에 따라 $0.48,0.51,0.52$ 로 나타나 김 분말 첨가 량에 따라 유의적으로 증가하였다 $(\mathrm{p}<0.05)$. 반고체 상태의 식품을 삼킬 수 있는 상태로 분해하는데 필요한 힘을 의미 하는 검성은 김 분말을 첨가하지 않는 대조군이 16.55 , 김 분말을 $1,2,3 \%$ 첨가 시 $38.33,59.17,71.07$ 로 김 분말을 첨가함에 따라 경도와 마찬가지로 유의적으로 증가하였 다 $(\mathrm{p}<0.05)$. 씹힘성은 식품을 씹는데 필요한 힘의 정도로 김 분말을 첨가하지 않는 대조군이 16.31 , 김 분말을 1 , $2,3 \%$ 첨가 시 $38.10,58.94,70.59$ 로 경도, 응집성, 검성, 씹힘성은 김 분말 첨가량에 따라 유의적으로 증가하는 것을 알 수 있었다 $(\mathrm{p}<0.05)$.

\section{관능평가}

김 분말 첨가 가나슈 초콜릿의 강도 결과는 Table 5 와 같다. 김의 색은 대조군이 1.0 점, $1,2,3 \%$ 첨가 시 2.5 , $4.4,5.9$ 점으로 첨가량에 따라 색의 강도가 유의적으로 높

Table 4. Texture of ganache added with different amounts of Porphyra tenera powder

\begin{tabular}{ccccc}
\hline & Control $^{1)}$ & PTP1 & PTP2 & PTP3 \\
\hline Hardness (g) & $35.98 \pm 1.19^{2) \mathrm{d} 3)}$ & $79.57 \pm 1.85^{\mathrm{c}}$ & $115.47 \pm 2.87^{\mathrm{b}}$ & $135.80 \pm 3.33^{\mathrm{a}}$ \\
Springiness & $0.99 \pm 0.01^{\mathrm{b}}$ & $0.99 \pm 0.00^{\mathrm{ab}}$ & $1.00 \pm 0.00^{\mathrm{a}}$ & $0.99 \pm 0.00^{\mathrm{ab}}$ \\
Cohesiveness & $0.46 \pm 0.01^{\mathrm{c}}$ & $0.48 \pm 0.01^{\mathrm{bc}}$ & $0.51 \pm 0.02^{\mathrm{ab}}$ & $0.52 \pm 0.03^{\mathrm{a}}$ \\
Gumminess & $16.55 \pm 0.50^{\mathrm{d}}$ & $38.33 \pm 1.65^{\mathrm{c}}$ & $59.17 \pm 1.82^{\mathrm{b}}$ & $71.07 \pm 2.91^{\mathrm{a}}$ \\
Chewiness & $16.31 \pm 1.36^{\mathrm{d}}$ & $38.10 \pm 0.65^{\mathrm{c}}$ & $58.94 \pm 1.91^{\mathrm{b}}$ & $70.59 \pm 2.76^{\mathrm{a}}$ \\
\hline
\end{tabular}

${ }^{1)}$ Control, ganache without Porphyra tenera powder; PTP1, 1\% Porphyra tenera powder ganache; PTP2, 2\% Porphyra tenera powder ganache; PTP3, 3\% Porphyra tenera powder ganache.

${ }^{2)}$ All values are mean \pm SD.

${ }^{3) a-d}$ Different letters in the same row are significantly different by Duncan's multiple range test at $\mathrm{p}<0.05$. 
Table 5. Sensory characteristics of ganache chocolate added with different amounts of Porphyra tenera powder

\begin{tabular}{|c|c|c|c|c|c|}
\hline & & Control $^{1)}$ & PTP1 & РTP2 & PTP3 \\
\hline \multirow{2}{*}{ Appearance } & Color & $1.0 \pm 0.0^{2 \mathrm{~d} 33)}$ & $2.5 \pm 0.7^{\mathrm{c}}$ & $4.4 \pm 1.0^{\mathrm{b}}$ & $5.9 \pm 1.2^{\mathrm{a}}$ \\
\hline & Smoothness & $5.7 \pm 1.3^{\mathrm{a}}$ & $3.9 \pm 1.0^{\mathrm{b}}$ & $3.4 \pm 1.2^{\mathrm{b}}$ & $3.4 \pm 1.6^{\mathrm{b}}$ \\
\hline \multirow{3}{*}{ Flavor } & РTP & $1.0 \pm 0.0^{\mathrm{c}}$ & $3.2 \pm 0.9^{\mathrm{b}}$ & $4.0 \pm 0.8^{\mathrm{ab}}$ & $4.7 \pm 1.3^{\mathrm{a}}$ \\
\hline & Sweet & $5.0 \pm 1.9^{\mathrm{a}}$ & $4.1 \pm 1.0^{\mathrm{ab}}$ & $3.9 \pm 0.9^{\mathrm{ab}}$ & $3.6 \pm 1.1^{b}$ \\
\hline & Chocolate & $5.7 \pm 1.1^{\mathrm{a}}$ & $4.5 \pm 1.2^{\mathrm{b}}$ & $4.4 \pm 0.8^{b}$ & $3.8 \pm 1.0^{\mathrm{b}}$ \\
\hline \multirow{4}{*}{ Taste } & РТP & $1.6 \pm 1.9^{c}$ & $4.0 \pm 0.9^{b}$ & $4.6 \pm 0.8^{\mathrm{ab}}$ & $5.7 \pm 1.3^{\mathrm{a}}$ \\
\hline & Sweet & $5.4 \pm 1.3^{\mathrm{a}}$ & $4.2 \pm 1.3^{\mathrm{b}}$ & $4.4 \pm 0.7^{\mathrm{b}}$ & $3.4 \pm 1.0^{\mathrm{b}}$ \\
\hline & Cream & $5.2 \pm 1.2^{\mathrm{a}}$ & $3.9 \pm 1.2^{\mathrm{b}}$ & $3.6 \pm 1.0^{\mathrm{b}}$ & $3.9 \pm 1.0^{\mathrm{b}}$ \\
\hline & Bitter & $2.4 \pm 1.4^{\mathrm{ns}}$ & $2.9 \pm 1.0$ & $2.9 \pm 0.9$ & $2.9 \pm 1.7$ \\
\hline \multirow{2}{*}{ Texture } & Hardness & $2.2 \pm 0.9^{\mathrm{c}}$ & $3.2 \pm 0.8^{\mathrm{bc}}$ & $4.1 \pm 1.1^{\mathrm{ab}}$ & $5.1 \pm 1.3^{\mathrm{a}}$ \\
\hline & Viscosity & $3.7 \pm 1.6^{\mathrm{NS} 4)}$ & $3.0 \pm 1.1$ & $3.3 \pm 1.7$ & $4.0 \pm 2.0$ \\
\hline
\end{tabular}

7 point scale (1, very weak; 2 , weak; 3 , slightly weak; 4, moderate; 5 , slightly strong; 6 , strong; 7 , very strong).

${ }^{1}$ Control, ganache without Porphyra tenera powder; PTP1, 1\% Porphyra tenera powder ganache; PTP2, 2\% Porphyra tenera powder ganache; PTP3, 3\% Porphyra tenera powder ganache.

${ }^{2)}$ All values are mean \pm SD.

${ }^{3) a-d}$ Different letters in the same row are significantly different by Duncan's multiple range test at $\mathrm{p}<0.05$.

${ }^{4} \mathrm{NS}$, not significant.

아졌다(p<0.05). 이는 색도의 결과에서 김 분말 첨가량이 높아질수록 L값이 낮아져 기계적 색도의 결과와 일치하 였다(Table 7). 단면의 매끄러운 정도는 대조군이 5.7점, 김 분말 첨가량을 $1,2,3 \%$ 첨가 시 $3.9,3.4,3.4$ 점으로 대조군과 김 분말 첨가군 간에는 유의적인 큰 차이를 나타 냈으나 $(\mathrm{p}<0.05)$, 김 분말 첨가군 간에는 유의적인 차이가 없었다. 김의 향은 대조군이 1.0 점, 김 분말 첨가량을 1 , $2,3 \%$ 첨가 시 $3.2,4.0,4.7$ 점으로 김 햠량이 많을수록 김 향이 높아져 유의적인 차이가 있음을 알 수 있었다 $(\mathrm{p}<0.05)$. 단향은 대조군이 5.0점으로 가장 높았으며 김 분말 첨가량 $1,2,3 \%$ 첨가 시 $4.1,3.9,3.6$ 점으로 대조군과 PTP1, PTP2는 유의적인 차이가 없었으나, PTP3는 유의적 인 차이를 보였다 $(\mathrm{p}<0.05)$. 초콜릿 향은 대조군이 가장 강 하게 나타나 5.7점, 김 분말 첨가량이 $1,2,3 \%$ 첨가 시 $4.5,4.4,3.8$ 점으로 김 첨가량이 많을수록 초콜릿 향이 감 소하였다. 김의 맛은 대조군이 1.6 점, 김 분말 첨가량이 $1,2,3 \%$ 첨가 시 $4.0,4.6,5.7$ 점으로 첨가량이 많을수록 유의적으로 높게 나타났으며, 대조군과는 유의적인 차이 를 보였다 $(\mathrm{p}<0.05)$. 단맛은 대조군에 비해 $1,2,3 \%$ 첨가군 은 유의적으로 단맛이 감소하였으나 $(\mathrm{p}<0.05)$, 첨가군간 유 의적 차이를 보이지 않았다. 크림 맛은 김 분말 함량에 따라 낮게 나타났다. 쓴맛은 유의적인 차이가 없었다. 경 도는 김 분말 첨가하지 않는 대조군이 2.2점, 김 분말 1 , $2,3 \%$ 로 첨가량을 높일수록 $3.2,4.1,5.1$ 점으로 유의적인 차이가 나타나, 김 분말 함량이 증가시킬수록 단단해짐을
알 수 있었다 $(\mathrm{p}<0.05)$. 이는 조직감의 측정 결과에서 김 분말 첨가량이 높을수록 경도가 높아졌다는 결과와 일치 한 경향을 나타냈다. 점착성은 대조군과 김 첨가군 간에는 유의적인 차이가 없었다.

김 분말 첨가 가나슈 초콜릿의 기호도 결과는 Table 6 과 같다. 관능평가 평점은 색 4.1-5.3점, 향 4.1-5.4점, 맛 4.0-5.3점, 조직감 4.4-4.9점, 전반적인 기호도 4.1-5.1 점, 구입할 의향 3.5-4.7점의 범위를 보였다. 전반적인 기호도는 김 분말 $1 \%$ 첨가 초콜릿이 5.1 점으로 가장 높게 평가되었다. 색은 김 분말 $1 \%$ 첨가군에서 가장 기호도가 높았으며, 김 분말을 첨가하지 않는 대조군은 4.4점, 김 분말 $2,3 \%$ 첨가 시 $4.1,4.3$ 점으로 유의적인 차이가 없었 다. 이와 같은 결과는 $2 \%$ 이상 첨가 시 김 색이 어둡게 보여 초콜릿의 기호가 낮아진 것으로 사료된다. 향은 김 분말 $1 \%$ 첨가군에서 5.4 점으로 가장 높았으며, 대조군 4.1 점, 김 분말 첨가량이 $2,3 \%$ 첨가 시 $4.1,4.3$ 점으로 유의적 인 차이를 보이지 않았다. 이는 색과 향의 기호가 일치하 는 경향을 보였다. 맛은 색, 향의 결과와 마찬가지로 김 분말 $1 \%$ 첨가군의 점수가 가장 높게 평가되었다. 조직감 은 대조군과 김 분말 첨가군 간에 유의적인 큰 차이를 보이지 않았다. 구입할 의향은 김 분말 $1 \%$ 첨가군이 4.7 점 으로 가장 높게 나타났다. 관능검사의 결과에 따르면 김 분말을 첨가하지 않는 대조군보다 김 분말 $1 \%$ 첨가 시 색, 향, 맛, 전반적인 기호도에서 유의적으로 높게 평가되었 다. 감마선 조사된 미역귀 열수추출물을 분말화시켜 첨가 
Table 6. Sensory preference results of ganache chocolate added with different amounts of Porphyra tenera powder

\begin{tabular}{ccccc}
\hline & Control $^{1)}$ & PTP1 & PTP2 & PTP3 \\
\hline Color & $4.4 \pm 1.1^{2) \mathrm{b} 3)}$ & $5.3 \pm 1.0^{\mathrm{a}}$ & $4.1 \pm 1.2^{\mathrm{b}}$ & $4.3 \pm 0.2^{\mathrm{b}}$ \\
Flavor & $4.1 \pm 1.5^{\mathrm{b}}$ & $5.4 \pm 1.0^{\mathrm{a}}$ & $4.1 \pm 1.4^{\mathrm{b}}$ & $4.3 \pm 0.3^{\mathrm{b}}$ \\
Taste & $4.0 \pm 1.5^{\mathrm{b}}$ & $5.3 \pm 1.1^{\mathrm{a}}$ & $4.1 \pm 1.4^{\mathrm{b}}$ & $4.3 \pm 0.3^{\mathrm{b}}$ \\
Texture & $4.4 \pm 1.2^{\mathrm{NS} 4)}$ & $4.9 \pm 1.3$ & $4.4 \pm 1.4$ & $4.6 \pm 1.4$ \\
$\begin{array}{c}\text { Overall } \\
\text { acceptability }\end{array}$ & $4.1 \pm 1.4^{\mathrm{b}}$ & $5.1 \pm 1.2^{\mathrm{a}}$ & $4.1 \pm 1.3^{\mathrm{b}}$ & $4.3 \pm 0.3^{\mathrm{b}}$ \\
$\begin{array}{c}\text { Buying } \\
\text { intention }\end{array}$ & $3.5 \pm 1.4^{\mathrm{b}}$ & $4.7 \pm 1.3^{\mathrm{a}}$ & $3.8 \pm 1.5^{\mathrm{b}}$ & $4.1 \pm 1.6^{\mathrm{b}}$ \\
\hline
\end{tabular}

7 point scale (1, dislike very much; 2 , dislike; 3, dislike slightly; 4, moderate; 5 , like slightly; 6 , like; 7 , like very much)

${ }^{1)}$ Control, ganache without Porphyra tenera powder; PTP1, 1\% Porphyra tenera powder ganache; PTP2, $2 \%$ Porphyra tenera powder ganache; PTP3, 3\% Porphyra tenera powder ganache.

${ }^{2)}$ All values are mean $\pm \mathrm{SD}$.

3)a,b Different letters in the same row are significantly different by Duncan's multiple range test at $\mathrm{p}<0.05$

${ }^{4)} \mathrm{NS}$, not significant.

한 초콜릿의 관능평가 결과에서도(Kim 등, 2012b) $3 \%$ 이상 첨가 시에는 선호도가 낮아지는 것으로 조사되었고, 김 분말을 첨가한 쿠키의 품질 특성에 관한 연구에서도 유사 한 결과를 나타냈다(Lee 등, 2017). 따라서 총 중량의 $1 \%$ 수준으로 김 분말을 첨가했을 때 색, 향, 맛의 조화가 이루 어져 전반적인 기호도가 높은 것으로 사료된다. 이에 따라 관능에 만족도가 높은 김 분말 첨가 초콜릿의 개발 가능성 이 있다고 사료된다.

\section{수분 함량}

김 분말을 첨가한 가나슈의 수분 함량 측정결과는 Table 7 과 같다. 김 분말을 첨가하지 않는 대조군의 수분 함량은 $6.79 \%$ 이었고, 김 분말 첨가량을 $1,2,3 \%$ 로 증가시킬수록 수분 함량은 각각 $4.49,4.21,3.73 \%$ 로 김 분말 첨가량에 따라 수분 함량은 유의적으로 감소하는 경향을 나타냈다. 대조군의 수분 함량이 김 분말 첨가군에 비해 유의적으로 가장 높게 나타났다 $(\mathrm{p}<0.05)$. 소청룡탕 한약 농축 분말을 첨가한 초콜릿의 제조에서도 한약 농축 분말의 첨가량을 증가시킬수록 수분 함량이 낮아졌으며(Yoo 등, 2005), 건 오디박 이화학적 품질 특성에서 오디박 첨가량이 많아질 수록 수분 함량이 낮아졌다(Hwang 등, 2012). 커피 폐원두 박을 이용한 초콜릿 연구에서도 폐원두박의 함량이 증가 함에 따라 수분 함량이 유의적으로 감소하였던 결과와 유사하였다(Yoo, 2011). 이는 $10.4-11.4 \%$ 로 수분 함량이 적은 김 분말의 고형분 함량이 증가하고, $52.5 \%$ 로 상대적 으로 수분 함량을 많이 보유하고 있는 생크림 양이 증가하 면서 수분 함량이 낮아지는 경향을 보이는 것으로 사료된
Table 7. Moisture, sugar, reducing sugar, $\mathrm{pH}$ and acidity of ganache added with different amounts of Porphyra tenera powder

\begin{tabular}{ccccc}
\hline & Control $^{1)}$ & PTP1 & PTP2 & PTP3 \\
\hline $\begin{array}{c}\text { Moisture } \\
\text { content } \\
(\%)\end{array}$ & $6.79 \pm 0.13^{2) \mathrm{a} 3)}$ & $4.49 \pm 0.05^{\mathrm{b}}$ & $4.21 \pm 0.06^{\mathrm{c}}$ & $3.73 \pm 0.13^{\mathrm{d}}$ \\
$\begin{array}{c}\text { Sugar } \\
\text { content } \\
\left({ }^{\circ} \text { Brix }\right)\end{array}$ & $45.33 \pm 0.58^{\mathrm{c}}$ & $47.67 \pm 0.58^{\mathrm{b}}$ & $52.00 \pm 0.00^{\mathrm{a}}$ & $52.67 \pm 0.58^{\mathrm{a}}$ \\
$\begin{array}{c}\text { Reducing } \\
\text { sugar } \\
\text { content } \\
(\%)\end{array}$ & $9.07 \pm 0.00^{\mathrm{d}}$ & $10.56 \pm 0.00^{\mathrm{c}}$ & $11.40 \pm 0.01^{\mathrm{b}}$ & $11.78 \pm 0.01^{\mathrm{a}}$ \\
$\begin{array}{c}\text { pH } \\
\begin{array}{c}\text { Acidity } \\
(\%)\end{array}\end{array}$ & $6.49 \pm 0.03^{\mathrm{a}}$ & $6.38 \pm 0.02^{\mathrm{b}}$ & $6.33 \pm 0.01^{\mathrm{c}}$ & $6.28 \pm 0.00^{\mathrm{d}}$ \\
\hline
\end{tabular}

${ }^{1)}$ Control, ganache without Porphyra tenera powder; PTP1, $1 \%$ Porphyra tenera powder ganache; PTP2, 2\% Porphyra tenera powder ganache; PTP3, 3\% Porphyra tenera powder ganache.

2) All values are mean $\pm \mathrm{SD}$.

3)a-d Different letters in the same row are significantly different by Duncan's multiple range test at $\mathrm{p}<0.05$.

다(NAS, 2016).

\section{당도 및 환원당}

김 분말을 첨가한 가나슈의 당도 및 환원당의 측정 결과 는 Table 7과 같다. 당도는 김 분말을 첨가하지 않는 대조 군이 $45.33{ }^{\circ} \mathrm{Brix}$ 로 가장 낮았으며, 김 분말 첨가량을 1 , $2,3 \%$ 로 증가시킬수록 당도는 $47.67,52.00,52.67 \%$ 로 김 분말 첨가량에 따라 증가하는 경향을 보였다.

환원당은 당도와 마찬가지로 김 분말을 첨가하지 않는 대조군이 $9.07 \%$ 로 가장 낮았으며, $1,2,3 \%$ 로 증가시킬수록 환원당은 $10.56,11.40,11.78 \%$ 로 유의적으로 증가하는 것 을 알 수 있었다 $(\mathrm{p}<0.05)$. 김 분말 첨가군이 김 분말을 넣지 않은 대조군보다 당 함량은 유의적으로 높았다 $(\mathrm{p}<0.05)$. 마른 김을 첨가하여 제조한 흑미 쿠키의 품질 특성에 관한 연구에서 김 분말 첨가량이 증가함에 따라 당도가 증가하 는 유사한 결과를 나타냈다(Hwang과 Nhuan 등, 2014). 이 는 김에 당질과 섬유질이 풍부하며, 김의 porphyran이라는 수용성 다당류로 인해 당도와 환원당에 영향을 미치는 것 으로 사료된다(Hwang과 Nhuan 등, 2014).

\section{$\mathrm{pH}$ 및 산도}

김 분말을 첨가한 가나슈의 $\mathrm{pH}$ 및 산도 측정결과는 Table 7과 같다. 김 분말을 첨가하지 않는 대조군의 $\mathrm{pH}$ 는 6.49 , 김 분말 첨가량을 $1,2,3 \%$ 로 증가시킬수록 $\mathrm{pH}$ 는 $6.38,6.33,6.28$ 로 김 분말 첨가량이 증가함에 따라 $\mathrm{pH}$ 도 유의적으로 감소하였다 $(\mathrm{p}<0.05)$. 일반적으로 초콜릿의 $\mathrm{pH}$ 
는 첨가한 부재료에 함유된 유기산의 함량에 따라 달라진 다고 알려진 바 있다(Choi 등, 2018). 이는 김에 함유된 카르복실기, 황산기를 포함하는 해조 다당류 및 폴리페놀 화합물에 의한 것으로 보고되었으며, 김에 다량 함유된 무기질인 칼륨, 인, 칼슘, 마그네슘 및 나트륨도 $\mathrm{pH}$ 에 영향 을 미친 것으로 사료된다(Hwang, 2013).

산도는 김 분말을 첨가하지 않는 대조군이 $0.49 \%$ 였으 며, 김 분말 첨가량을 $1,2,3 \%$ 로 증가시킬수록 산도는 $0.52,0.57,0.67 \%$ 로 유의적으로 증가하였다 $(\mathrm{p}<0.05)$. 건 오디박을 첨가한 초콜릿(Hwang 등, 2012), 숙지황 농축액 첨가 초콜릿(Kim 등, 2012a), 오디 첨가 초콜릿(Park과 Joo, 2011), 아로니아 첨가 초콜릿(Park, 2014)의 연구 결과에서 도 부재료 첨가량의 증가에 따라 $\mathrm{pH}$ 가 감소하는 결과로 본 연구결과와 유사하였다. 김의 chlorophyll 색소는 고온 뿐 아니라, 산에 의해서도 pheophytin a로 분해되어 황갈색 의 색소물질이 형성되는데(Lee와 Choi, 1973), 본 연구에 서는 김의 첨가량이 증가할수록 $\mathrm{pH}$ 는 낮아지고 산도가 증가하였으므로 이러한 결과는 색도에도 영향을 미쳐 색 도 측정 시에 녹색도는 감소하고, 적색도가 증가한 것과 유사한 결과를 나타낸 것으로 사료된다.

\section{피코시아닌 및 클로로필 함량}

김 분말을 첨가한 가나슈 $100 \mathrm{~g}$ 에 대한 피코시아닌 및 클로로필의 함량은 Table 8과 같다. C-phycocyanin은 대조 군이 $0.0015 \mathrm{~g}$, 김 분말을 $1,2,3 \%$ 첨가 시 $0.0016,0.0021$, $0.0024 \mathrm{~g}$ 으로 김 분말 첨가량이 많아질수록 피코시아닌 함량 은 유의적으로 증가하였다 $(\mathrm{p}<0.05)$. Allophycocyanin은 대조 군이 $0.0039 \mathrm{~g}$, 김 분말을 $1,2,3 \%$ 첨가 시 $0.0061,0.0081$, $0.0108 \mathrm{~g}$ 으로 김 분말 첨가량에 따라 유의적으로 증가하였 다 $(\mathrm{p}<0.05)$. 피코시아닌 총량은 대조군이 $0.0053 \mathrm{~g}$, 김 분말 을 $1,2,3 \%$ 첨가 시에 $0.0078,0.0102,0.0132 \mathrm{~g}$ 으로 김 분말의 첨가 수준에 비례하여 유의적으로 증가하였으며,
C-phycocyanin과 allophycocyanin의 함량과 일치하는 경향 을 보였다 $(\mathrm{p}<0.05)$. 김에는 색을 나타내는 수용성 색소단 백질이 존재하는데, 적색을 나타내는 phycoerythrin, 청색 을 나타내는 것은 phycocyanin이라고 하였고(Kim과 Nam, 1976), 김 주요 색소는 phycoerythin, phycocyanin, chlorophyll $\mathrm{a}$ 라고 보고되었다(Jeon 등, 2017). 피코시아닌은 항염증, 항산화성의 효과가 있어 김을 이용한 식품개발에 도움이 될 것으로 기대된다(Eriksen, 2008; Romay 등, 1998).

Chlorophyll a는 김 분말을 첨가하지 않는 대조군이 $0.00029 \mathrm{~g}$, 김 분말을 $1,2,3 \%$ 로 첨가 시 $0.00030,0.00032$, $0.00035 \mathrm{~g}$ 으로 김 분말 첨가량에 따라 유의적으로 증가하였 으며 $(\mathrm{p}<0.05)$, chlorophyll $\mathrm{b}$ 는 김 분말을 첨가하지 않는 대 조군이 $0.00058 \mathrm{~g}$, 김 분말을 $1,2,3 \%$ 첨가 시 0.00061 , $0.00066,0.00071 \mathrm{~g}$ 으로 유의적으로 증가하였다 $(\mathrm{p}<0.05)$. Total chlorophyll 또한 김 분말을 첨가하지 않는 대조군이 $0.00087 \mathrm{~g}$, 김 분말을 $1,2,3 \%$ 첨가 시 $0.00092,0.00098$, $0.00106 \mathrm{~g}$ 으로 유의적으로 증가하였다 $(\mathrm{p}<0.05)$. Hong 등 (1997)의 김 추출물의 이화학적 특성에 관한 연구에서 김의 클로로필과 카로티노이드 함량이 높다고 보고된 바 있어 김 분말 첨가량이 많을수록 클로로필 함량이 유의적으로 증가한 결과를 보인 것으로 사료 된다. 김에 함유된 항산화 물질 중 하나인 클로로필, 카로티노이드, 피코빌린 등의 색 소 성분은 산화 방지성분으로 다량 함유되어 있다는 연구결 과를 바탕으로 김 첨가로 인한 항산화 활성 증진과 기능성 초콜릿의 제품 개발 가능성이 기대된다(Nguen 등, 2018).

\section{총 페놀 함량}

김 분말 첨가 가나슈 $100 \mathrm{~g}$ 에 대한 총 페놀 함량의 결과 는 Fig. 2 와 같다. 김 분말을 첨가하지 않은 대조군의 총 페놀 함량은 $0.214 \mathrm{~g}$, 김 분말을 $1,2,3 \%$ 첨가 시 0.618 , $0.648,0.867 \mathrm{~g}$ 으로 김 분말 첨가량이 증가할수록 총 페놀 함량이 유의적으로 증가하였다(p<0.05). 홍조류에는 ca-

Table 8. Phycocyanin and chlorophyll contents of ganache added with different amounts of Porphyra tenera powder

\begin{tabular}{cccccc}
\hline & & Control $^{1)}$ & PTP1 & PTP2 & PTP3 \\
\hline & C-Phycocyanin & $0.0015 \pm 0.0000^{2) \mathrm{d} 3)}$ & $0.0016 \pm 0.0001^{\mathrm{c}}$ & $0.0021 \pm 0.0001^{\mathrm{b}}$ & $0.0024 \pm 0.0001^{\mathrm{a}}$ \\
$\begin{array}{c}\text { Phycocyanin } \\
(\mathrm{g} / 100 \mathrm{~g})\end{array}$ & Allophycocyanin & $0.0039 \pm 0.0001^{\mathrm{d}}$ & $0.0061 \pm 0.0002^{\mathrm{c}}$ & $0.0081 \pm 0.0004^{\mathrm{b}}$ & $0.0108 \pm 0.0006^{\mathrm{a}}$ \\
& Total phycocyanin & $0.0053 \pm 0.0001^{\mathrm{d}}$ & $0.0078 \pm 0.0002^{\mathrm{c}}$ & $0.0102 \pm 0.0004^{\mathrm{b}}$ & $0.0132 \pm 0.0005^{\mathrm{a}}$ \\
\hline & Chlorophyll a & $0.00029 \pm 0.00001^{\mathrm{d}}$ & $0.00030 \pm 0.00001^{\mathrm{c}}$ & $0.00032 \pm 0.00001^{\mathrm{b}}$ & $0.00035 \pm 0.00001^{\mathrm{a}}$ \\
$\begin{array}{c}\text { Chlorophyll } \\
(\mathrm{g} / 100 \mathrm{~g})\end{array}$ & Chlorophyll b & $0.00058 \pm 0.00001^{\mathrm{d}}$ & $0.00061 \pm 0.00001^{\mathrm{c}}$ & $0.00066 \pm 0.00001^{\mathrm{b}}$ & $0.00071 \pm 0.00000^{\mathrm{a}}$ \\
& Total chlorophyll & $0.00087 \pm 0.00001^{\mathrm{d}}$ & $0.00092 \pm 0.00001^{\mathrm{c}}$ & $0.00098 \pm 0.00001^{\mathrm{b}}$ & $0.00106 \pm 0.00001^{\mathrm{a}}$ \\
\hline
\end{tabular}

\footnotetext{
${ }^{1)}$ Control, ganache without Porphyra tenera powder; PTP1, 1\% Porphyra tenera powder ganache; PTP2, 2\% Porphyra tenera powder ganache; PTP3, 3\% Porphyra tenera powder ganache.

2) All values are mean $\pm \mathrm{SD}$.

3)a-d Different letters in the same row are significantly different by Duncan's multiple range test at $\mathrm{p}<0.05$.
} 


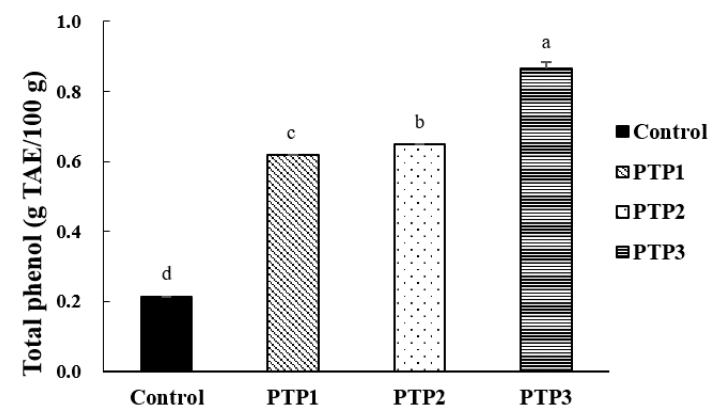

Fig. 2. Total phenol contents of ganache added with different amounts of Porphyra tenera powder.

Control, ganache without Porphyra tenera powder; PTP1, 1\% Porphyra tenera powder ganache; PTP2, $2 \%$ Porphyra tenera powder ganache; PTP3, 3\% Porphyra tenera powder ganache.

TAE, tannin acid equivalent.

All values are mean \pm SD

${ }^{\text {a-d }}$ Different letters above the bars are significantly different by Duncan's multiple range test at $\mathrm{p}<0.05$.

techin, phlorotannin 등과 같은 폴리페놀 화합물이 함유되 어 있다고 보고된 바 있어 김 분말 첨가량이 증가할수록 총 페놀 함량이 증가된 것으로 사료된다(Yan 등, 1999; Baek과 Kim, 2019). Kwak 등(2005)의 5종 해조류의 총 폴 리페놀 함량은 파래가 $8.97 \mathrm{mg} / \mathrm{g}$, 김이 $3.81 \mathrm{mg} / \mathrm{g}$ 으로 김에 는 폴리페놀 함량이 해조류 중에 파래 다음으로 높은 함량 을 보인 연구결과와 일치하였다.

\section{플라보노이드 함량}

김 분말 첨가 가나슈 $100 \mathrm{~g}$ 에 대한 플라보노이드 함량의 결과는 Fig. 3 과 같다. 김 분말을 첨가하지 않은 대조군의 플라보노이드 함량은 $0.056 \mathrm{~g}$, 김 분말을 $1,2,3 \%$ 첨가 시 $0.066,0.075,0.103 \mathrm{~g}$ 으로 김 분말 첨가량이 증가할수록

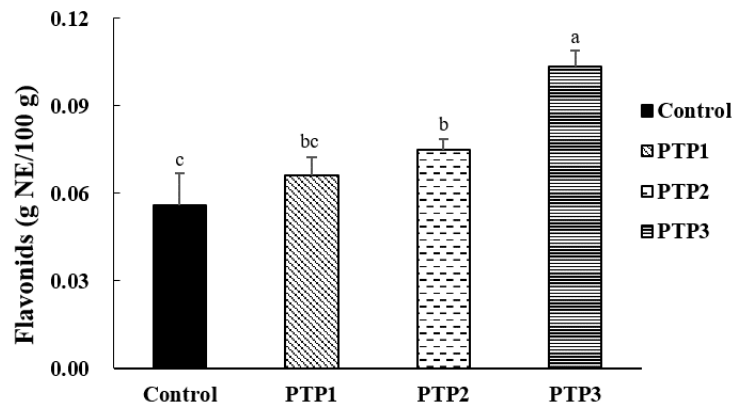

Fig. 3. Flavonoid contents of ganache added with different amounts of Porphyra tenera powder.

Control, ganache without Porphyra tenera powder; PTP1, 1\% Porphyra tenera powder ganache; PTP2, 2\% Porphyra tenera powder ganache; PTP3, 3\% Porphyra tenera powder ganache.

$\mathrm{NE}$, naringin equivalent.

All values are mean \pm SD

${ }^{\mathrm{a}-\mathrm{c}}$ Different letters above the bars are significantly different by Duncan's multiple range test at $\mathrm{p}<0.05$.
총 플라보노이드 함량이 유의적으로 증가하였다 $(\mathrm{p}<0.05)$. Lee 등(2017)은 김 분말에는 플라보노이드의 항산화 성분 들이 존재하여 쿠키의 항산화 활성에 기여하고, 쿠기 제조 시 김 분말 첨가량에 비례하여 쿠키의 총 페놀 함량이 증가하였다고 보고하였으며, 이는 김 분말 첨가량을 증가 시킬수록 플라보노이드의 함량이 높았던 본 실험 결과와 유사하였다. 플라보노이드는 항산화 작용, 항염, 항균 등 의 생리활성 효과를 가진다(Park 등, 2012). Kwak 등(2005) 의 한국산 5 종 해조류의 연구에서 총 플라보노이드의 함 량은 미역이 $11.33 \mathrm{mg} / \mathrm{g}$, 파래가 $4.65 \mathrm{mg} / \mathrm{g}$, 김이 $2.68 \mathrm{mg} / \mathrm{g}$ 의 함량을 나타낸 연구 결과와 같이 김 분말 첨가량을 증가시킬수록 플라보노이드의 함량이 높아진 결과를 나 타낸 것과 일치하였다.

\section{DPPH radical 소거능}

김 분말 첨가 가나슈의 $\mathrm{DPPH}$ radical 소거능의 $\mathrm{IC}_{50}$ 값은 Fig. 4 와 같다. 김 분말을 첨가하지 않은 대조군의 $\mathrm{IC}_{50}$ 값은 $334.01 \mathrm{mg} / \mathrm{mL}$, 김 분말을 $1,2,3 \%$ 첨가 시 $276.45,205.52$, $174.39 \mathrm{mg} / \mathrm{mL}$ 로 김 분말 첨가량이 증가할수록 $\mathrm{DPPH}$ radical 소거능의 $\mathrm{IC}_{50}$ 값은 유의적으로 감소하였다 $(\mathrm{p}<0.05)$. 감마선 조사된 미역귀 열수추출물을 분말화하여 초콜릿에 첨가하였을 때 첨가량이 증가할수록 높은 항산화 활성을 나타내었으며, 동일 첨가량일 때 감마선 조사 처리군이 대 조군보다 높은 활성이었다고 보고되어 있다 $(\mathrm{Kim}$ 등, 2012b). Hwang과 Nhuan(2014)의 마른 김을 첨가한 흑미 쿠키에서도 마른 김의 첨가 농도에 의존하여 유의적으로 증가하는 결과를 나타냈다. Lee 등(2012)의 건조 김의 $\mathrm{DPPH}$ radical 소거능의 연구에서 해남 김 $65.1 \%$, 서천 김 $56.1 \%$, 장흥 김이 $53.5 \%$ 로 항산능이 있다고 보고된 바 있 다. Ascorbic acid에 비해 항산화 활성은 낮지만, Seo 등

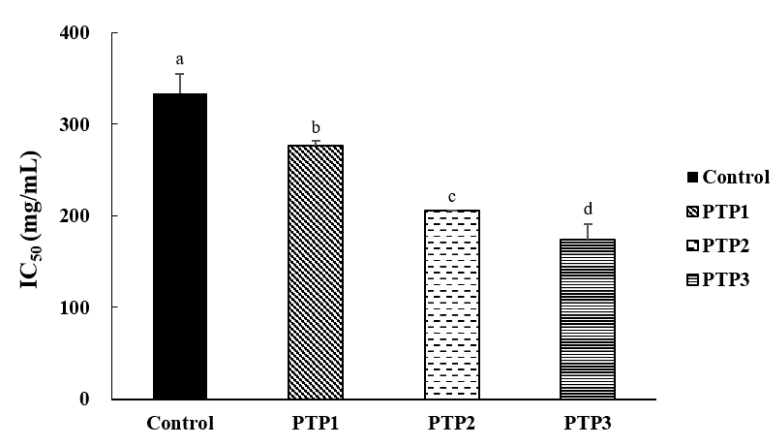

Fig. 4. DPPH radical scavenging activity of ganache added with different amounts of Porphyra tenera powder.

Control, ganache without Porphyra tenera powder; PTP1, 1\% Porphyra tenera powder ganache; PTP2, $2 \%$ Porphyra tenera powder ganache; PTP3, 3\% Porphyra tenera powder ganache.

All values are mean $\pm \mathrm{SD}$.

${ }^{a-d}$ Different letters above the bars are significantly different by Duncan's multiple range test at $\mathrm{p}<0.05$. 
(1999)에서 페놀성 화합물의 함량과 항산화 활성과는 높은 상관관계가 있다는 결과는 같은 경향을 나타냈다(Fig. 2).

\section{Superoxide dismutase(SOD) 유사활성}

김 분말 첨가 가나슈의 유사활성의 측정 결과는 Fig. 5 와 같다. 김 분말을 첨가하지 않은 대조군의 $\mathrm{SOD}$ 의 $\mathrm{EC}_{50}$ 값은 $1,951.46 \mathrm{mg} / \mathrm{mL}$, 김 분말을 $1,2,3 \%$ 로 첨가 시 729.63 , $689.44,528.28 \mathrm{mg} / \mathrm{mL}$ 로 김 분말 첨가량이 증가할수록 유 의적으로 감소하여 $\mathrm{SOD}$ 유사활성이 높아졌다( $<<0.05)$. 이 는 본 연구에서 김의 색소성분인 피코에스트린, 피코시아 닌, 클로로필의 함량 측정과 일치하는 경향이었다. SOD 유사활성을 갖는 항산화 물질로 phenolic acids, flavonoids, anthocyanins 및 isoflavonoids와 같은 페놀성 화합물들이 알려져 있어(Choudhary와 Swarnkar, 2011) 김의 catechin, phlorotannin 등과 같은 폴리페놀 화합물(Yan 등, 1999; Baek과 Kim, 2019)이 생리활성 기능을 비롯한 항산화성을 증진에 도움을 줄 것으로 사료된다.

\section{요 약}

본 실험은 초콜릿의 기능성을 부여하고자 가나슈에 김 분말 첨가량을 다르게 하여 제조한 후, 품질 특성과 항산화 성 및 기호도 조사를 통해 기능성 초콜릿의 제품 개발을 검토하고자 하였다. 이화학적 품질 특성을 평가한 결과는 다음과 같다. 색도는 김 분말 첨가량을 증가시킬수록 점점 어두워져 명도( $\mathrm{L}$ 값), 황색도(b값)는 낮아졌고, 적색도(a값) 는 증가하였다. 조직감은 경도는 김 분말 첨가량이 많아질 수록 높아져 단단해짐을 알 수 있었고, 응집성, 검성과 씹힘 성도 김 분말 첨가량에 따라 유의적으로 증가하였다. 탄력 성은 대조군과 김 분말 첨가량과는 유의적인 차이가 없었 다. 관능평가 시 전반적인 기호도에서 김 분말 첨가량이

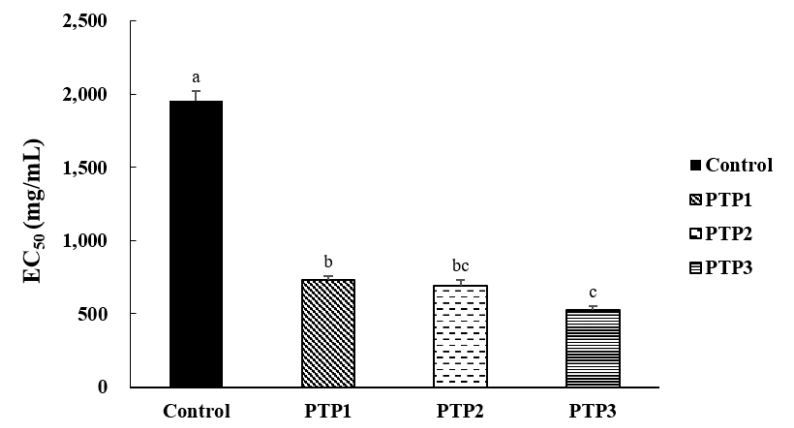

Fig. 5. SOD-like scavenging activity of ganache added with different amounts of Porphyra tenera powder.

Control, ganache without Porphyra tenera powder; PTP1, 1\% Porphyra tenera powder ganache; PTP2, 2\% Porphyra tenera powder ganache; PTP3, 3\% Porphyra tenera powder ganache.

All values are mean $\pm \mathrm{SD}$

${ }^{\mathrm{a}-\mathrm{c}}$ Different letters above the bars are significantly different by Duncan's multiple range test at $\mathrm{p}<0.05$.
$1 \%$ 일 때 가장 기호도가 높게 평가되었다. 색, 향, 맛에서도 기호도와 마찬가지로 김 분말 첨가량이 $1 \%$ 일 때 가장 높게 평가되었으며 $2,3 \%$ 첨가 시에는 유의적인 차이가 없었다. 조직감은 김 분말 첨가량 증가에 따라 유의적인 차이가 없었으며, 구입할 의향을 평가한 결과는 김 분말 $1 \%$ 첨가군 에서 기호도와 마찬가지로 가장 높게 평가되었다. 수분 함 량은 김 분말 첨가량을 $1,2,3 \%$ 로 증가시킬수록 수분 함량 은 감소하여 대조군과는 유의적인 차이를 보였다. 당도와 환원당은 김 분말 첨가량 증가에 따라 다소 높아져 유의적 인 차이를 보였다. $\mathrm{pH}$ 는 김 분말 첨가량이 증가할수록 낮아 졌으며, 반면 산도는 김 분말 함량이 증가할수록 산도가 증가하여 유의적인 차이를 나타냈다. 피코시아닌 함량은 김 분말 첨가량이 증가할수록 피코시아닌의 함량이 유의적 으로 증가하였고, 클로로필 함량도 김 분말 첨가량이 많을 수록 유의적으로 증가하였다. 항산화력이 강한 총 페놀 및 플라보노이드의 함량은 김 분말 첨가량이 증가할수록 높아 졌으며, DPPH radical의 소거능과 SOD 유사활성은 김 분말 첨가량이 증가할수록 높아졌다. 김 분말 첨가 시 항산화 활성과 관능적 기호도가 높아진 초콜릿의 개발이 가능할 것으로 보이며, 김을 이용한 제품개발을 위한 기초 자료로 사용될 것으로 기대된다.

\section{감사의 글}

이 논문은 2020년 해양수산부 재원으로 해양수산과학 기술진흥원의 지원을 받아 수행된 연구임(충청 씨그랜트).

\section{Conflict of interests}

The authors declare no potential conflict of interest.

\section{ORCID}

Min Ah Park https://orcid.org/0000-0003-3621-5698

Mee Ree Kim https://orcid.org/0000-0003-3813-1447

\section{References}

Bae SK. Recent advances in radioiodine therapy for thyroid cancer. Nucl Med Mol Imaging, 40, 132-140 (2006)

Baek SY, Kim MR. Comparison of quality characteristic and antioxidant activity of Enteromorpha prolifera from Seosan and Muan in Korea. J Korean Soc Food Sci Nutr, 48, 1070-1078 (2019)

Chappelle EW, Kim MS, McMurtrey III JE. Ratio analysis of reflectance spectra (RARS): An algorithm for the remote estimation of the concentrations of chlorophyll 
a, chlorophyll b, and carotenoids in soybean leaves. Remote Sens Environ, 39, 239-247 (1992)

Cho KJ, Lee YS, Ryu BH. Antitumor effect and immumology activity of seaweeds toward sarcoma-180. Korean J Fish Aquat Sci, 23, 345-352 (1990)

Choi KP, Chae DJ, Ryoo JE. Trends of chocolate industry in Korea. Food Industry and Nutriton, 19, 14-18 (2014)

Choi SH, Hwang ES. Quality characteristics and antioxidant activity of chocolate containing Chinese artichoke (Stachys sieboldii Miq.) powder. J Korean Soc Food Sci Nutr, 47, 39-45 (2018)

Choudhary RK, Swarnkar PL. Antioxidant activity of phenolic and flavonoid compounds in some medicinal plants of India. Nat Prod Res, 25, 1101-1109 (2011)

Eriksen NT. Production of phycocyanin-A pigment with applications in biology, biotechnology, foods and medicine. Appl Microbiol Biotechnol, 80, 1-14 (2008)

Goldstein A, Tachibana S, Lowney LI, Hunkapiller M, Hood L. Dynorphin-(1-13), an extraordinarily potent opioid peptide. Proc Natl Acad Sci USA, 76, 6666-6670 (1979)

Hong SP, Koo JK, Jo KS, Kim DS. Physicochemical characteristics of water or alcohol soluble extracts from laver, Porphyra yezoensis. J Korean Soc Food Sci Nutr, 26, 10-16 (1997)

Huang YW, Huang CY. Traditional oriental seafood products. In: Asian Foods: Science and Technology, Ang CYW, Liu K, Huang YW (Editors), CRC Press, London, England, p 270-272 (1999)

Hwang ES. Composition of amino acids, minerals, and heavy metals in differently cooked laver (Porphyra tenera). J Korean Soc Food Sci Nutr, 42, 1270-1276 (2013)

Hwang ES, Nhuan DT. Quality characteristics and antioxidant activities of black rice cookies with added dried laver (Porphyra tenera). Korean J Food Cook Sci, 30, $472-479$ (2014)

Hwang MH, Jeon HL, Kim HD, Lee SW, Kim MR. Quality characteristics and antioxidant activities of chocolate added with mulberry pomace. Korean J Food Cookery Sci, 28, 479-487 (2012)

Jenkins DJA, Kendall CWC, Axelsen M, Augustin LSA, Vuksan V. Viscous and nonviscous fibers, nonabsorbable and low glycaemic index carbohydrates, blood lipids and coronary heart disease. Curr Opin Lipidol, 11, 49-56 (2000)

Jeon HJ, Seon AL, Son MH, Cho HS, Kim PJ. A effect of acid treatment on Porphyra pigment. J Korean Soc Mar Environ Energy, 20, 219-225 (2017)
Jung KJ, Jung BM, Kim SB. Effect of porphyran isolated from laver, Porphyra yezoensis, on liver lipid peroxidation in hyperlipidemic rats and on immunological functions in mice. Korea J Food Sci Technol, 34, 325-329 (2002)

Kim CR, Park HJ, Oh HL, Na YG, Doh ES, Yoon JH, Shim EK, Kim MR. Quality characteristics and antioxidant activity of chocolate added with Rehmannia Radix Preparata concentrate. J East Asian Soc Dietary Life, 22, 535-542 (2012a)

Kim DM, Kim KH, Yook HS. Quality characteristics of chocolate with added hot water extracts of Undaria pinnatifida Sporophylls under gamma irradiation. J Korean Soc Food Sci Nutr, 41, 103-109 (2012b)

Kim JP, Nam KS. Isolation of chromoprotein and its amino acids composition in Korean laver. Korean J Food Sci Techonol, 8, 172-178 (1976)

Kim SH, Lee AJ. Market segmentation difference on motivation of chocolate consumption experience. FoodService Industry J, 11, 67-77 (2015)

Kim SH, Park HY, Park WK. Determination and physical properties of dietary fiber in seaweed products. J Korean Soc Food Nutr, 17, 320-325 (1988)

Kwak CS, Kim SA, Lee MS. The correlation of antioxidative effects of 5 Korean common edible seaweeds and total polyphenol content. J Korean Soc Food Sci Nutr, 34, 1143-1150 (2005)

Kweon BM, Jeon SW, Kim DS. Quality characteristics of sponge cake with addition of laver powder. J Korean Soc Food Sci Nutr, 32, 1278-1284 (2003)

Kwon MY, Sung HJ. Immunity fuction modulate of complement activity polysaccharide. Korean J Soc Food Sci Technol, 30, 30-43 (1997)

Lee GW, Choi MJ, Jung BM. Quality characteristics and antioxidative effect of cookies made with Capsosiphon fulvescens powder. Korean J Food Cook Sci, 26, 381-389 (2010)

Lee HJ, Choi JI, Choi SJ. Physiological activities and amino acid compositions of Korean dried laver Porphyra products. Korean J Fish Aquat Sci, 45, 409-413 (2012)

Lee JA, Song LS, Yoon JY. Quality characteristics of cookies with added dried laver (Porphyra tenera) powder. Culinary Science Hospitality Research, 23, 88-96 (2017)

Lee JY, Lee SH, Lee HG, Park KH, Choe EO. Spinach (Spinacia oleracea) powder as a natural food-grade antioxidant in deep-fat-fried products. J Agric Food 
Chem, 50, 5664-5669 (2002)

Lee KH, Choi HY. Water activity and pigment degradation in dried lavers stored at room temperature. Korean J Fish Aquat Sci, 6, 27-36 (1973)

Lee KH, Jang HJ, Lee YJ, Choi JH. Changes in the chemical components and antioxidant activity of peach (Prunus persica L. Batsch) by hot air treatment. Korean J Food Nutr, 27, 219-224 (2014)

Lee KH, Song SH, Jeong IH. Quality changes of dried lavers during processing and storage: 1 . Quality evaluation of different grades of dried lavers and its changes during storage. Bull Korean Fish Soc, 20, 408-418 (1987)

Lee TS, Lee HJ, Byun HS, Kim JH, Park MJ, Park HY, Jung KT. Effect of heat treatment in dried lavers and modified processing. J Korean Fish Soc, 33, 529-532 (2000)

Marklund S, Marklund G. Involvement of the superoxide anion radical in the autoxidation of pyrogallol and a convenient assay for superoxide dismutase. Eur J Biochem, 47, 469-474 (1974)

MOF. http://www.fips.go.kr/p/S020304/. Fisheries Statistics, Ministry of Oceans and Fisheries, Sejong, Korea (accessed Sep 2019)

NAS. Korean Food Composition Table. 9th ed, National Institute of Agricultural Sciences, Wanju, Korea (2016)

Nguyen TT, Choi YJ, Nguyen THP, Neri TA, Choi BD. Change in the antioxidant activity of roasted seasoned laver Pyropia yezoensis with heat processing and storage. Korean J Fish Aquat Sci, 51, 362-368 (2018)

Park BH, Choi HK, Cho HS. A study on oxidative stability and quality characteristic of Kimbugak made of aqueous green tea. J Korean Soc Food Sci Nutr, 30, 577-564 (2001a)

Park CK. The kinds of laver products and their efficient methods for roasting, preservation, and utilization. Bull Fish Sci Inst, Yosu Nat'l Univ, 10, 67-72 (2001b)

Park HR. Antioxidative effect of Aronia melanocarpa on white chocolate ganache. MS Thesis, Sejong University, Korea (2014)

Park JD, Choi BK, Kum JS, Lee HY. Quality properties of cooked germinated-brown rice. Korean J Food Preserv, 12, 101-106 (2005)

Park S, Chae KS, Son RH, Jung J, Im YR, Kwon JW. Quality characteristics and antioxidant activity of Bokbunja (black raspberry) vinegars. Food Eng Prog, 16, 340-346 (2012)

Park SY, Joo NM. Processing optimization and antioxidant activity of chocolate added with mulberry. Korean J Food Sci Technol, 43, 303-314 (2011)

Rein D, Paglieroni TG, Wun T, Pearson DA, Schmitz HH, Gosselin R, Keen CL. Cocoa inhibits platelet activation and function. Am J Clin Nutr, 72, 30-35 (2000)

Romay C, Armesto J, Remirez D, Gonzalez R, Ledon N, Garcia I. Antioxidant and anti-inflammatory properties of C-phycocyanin from blue-green algae. Inflammation Res, 47, 36-41 (1998)

Seo YH, Kim IJ, Yie AS, Min HK. Electron donating ability and contents of phenolic compounds, tocopherols and carotenoids in waxy corn (Zea mays L.). Korean J Food Sci Technol, 31, 581-585 (1999)

Shin JH, Joo NM. Processing optimization of chocolate with fermented and aged garlic extract. Korean J Food Culture, 25, 216-224 (2010)

Singleton VL, Orthofer R, Lamuela-Raventos Rm. Analysis of total phenols and other oxidation substrates and antioxidants by means of Folin-Ciocalteu's reagent. Methods Enzymol, 299, 152-178 (1999)

Vlachopoulos C, Alexopoulos N, Stefanadis C. Effects of dark chocolate on arterial function in healthy individuals: Cocoa instead of ambrosia?. Curr Hypertens Rep, 8, 205-211 (2006)

Yan X, Chuda Y, Suzuki M, Nagata T. Fucoxanthin as the major antioxidant in Hijikia fusiformis, a common edible seaweed. Biosci Biotechnol Biochem, 63, 605-607 (1999)

Yoo KM, Lee KW, Moon BK, Hwang IK. Antioxidant characteristics and preparation of chocolate added with Sochungryong-tang (oriental medicinal plants extract). Korean J Food Cookery Sci, 21, 585-590 (2005)

Yoo KM, Song MR, Ji EJ. Preparation and sensory characteristics of chocolate with added coffee waste. Korean J Food Nutr, 24, 111-116 (2011)

Yoon MH, Kim KH, Hwang HR, Jo JE, Kim MS, Yook HS. Quality characteristics and antioxidant activity of chocolate containing flowering cherry (Prunus serrulata L. var. spontanea Max. wils.) fruit powder. J Korean Soc Food Sci Nutr, 38, 1600-1605 (2009)

Youn HY, Lee SJ. Quality characteristics of chocolate ganache influenced by the level of vegetable creams. Food Eng Prog, 16, 306-313 (2012)

Yu OK, Kim MA, Rho JO, Sohn HS, Cha YS. Quality characteristics and the optimization recipes of chocolate added with Bokbunja (Rubus coreanus Miquel). J Korean Soc Food Sci Nutr, 36, 1193-1197 (2007) 